Fall 2007

\title{
Marketing as Constructive Engagement
}

Clifford J. Shultz

Loyola University Chicago, cshultz@luc.edu

Follow this and additional works at: https://ecommons.luc.edu/business_facpubs

Part of the Business Commons

\section{Recommended Citation}

Shultz, CJ. "Marketing as constructive engagement" in Journal of Public Policy \& Marketing 26(2), 2007.

This Article is brought to you for free and open access by the Faculty Publications and Other Works by Department at Loyola eCommons. It has been accepted for inclusion in School of Business: Faculty Publications and Other Works by an authorized administrator of Loyola eCommons. For more information, please contact ecommons@luc.edu.

\section{(c) $($ () $\ominus$}

This work is licensed under a Creative Commons Attribution-Noncommercial-No Derivative Works 3.0 License.

(c) American Marketing Association, 2007. 


\title{
Marketing as Constructive Engagement
}

\author{
Clifford J. Shultz II
}

\begin{abstract}
The purpose of this essay is to provoke a more comprehensive, historically accurate, and meaningful definition of marketing. Toward that outcome, the author introduces a framework for marketing that argues for constructive engagement with a complex, conflicted, and increasingly interdependent world in which marketing can and should play an important role. The framework offers a new synthesis commensurate with ideals generally espoused in macromarketing. An illustration based on longitudinal study of Vietnam is shared, with implications for current global affairs and with new directions for meaningful marketing research and practice.
\end{abstract}

T he two most recent definitions of marketing, as posited by thoughtful members of the American Marketing Association (AMA) in 2004 and 2007, have generated considerable discussion about the nature, scope, and foci of marketing. 1 The 2004 definition is neither fully embraced by AMA members nor uniformly adopted by other marketing organizations and associations around the world, where some of the most compelling marketing activity now unfolds. Thus, in 2007, the AMA proposed a revised definition. My own take on both definitions, though I believe that they are useful to the practice of marketing management, with some orientation to societal issues, is that they are too microscopic, do not coincide particularly well with historical interpretations of marketing, and ultimately (tragically?) limit the potential impact of marketing on some of the most pressing challenges. In this essay, therefore, I briefly remind readers of some historical roots and foci of marketing and introduce a conceivable alternative definition and a (macro)marketing synthesis for constructive engagement. I also provide a brief application of this synthesis, using historical and evolving U.S.-Vietnam relations and Nike's

1The 2004 definition is as follows: "Marketing is an organizational function and a set of processes for creating, communicating, and delivering value to customers and for managing customer relationships in ways that benefit the organization and its stakeholders." The 2007 working definition is as follows: "Marketing is the activity, conducted by organizations and individuals, that operates through a set of institutions and processes for creating, communicating, delivering, and exchanging market offerings that have value for customers, clients, marketers, and society at large." This article was largely written before the wide dissemination of this most recently proposed working definition, and though this definition is more in line with ideas expressed here, I still believe that it limits marketing's potential impact and falls short of other potentially more macro and societal-centric definitions, for reasons articulated in the text.

Clifford J. Shultz I/ is a professor and Marley Foundation Chair, ASU Morrison School of Management and Agribusiness, Arizona State University, and is editor of the Journal of Macromarketing (e-mail: atcjs@asu.edu). The author thanks Roger Dickinson, Sanford Grossbart, Greg Gundlach, Morris Holbrook, Tony Pecotich, Stan Shapiro, Bill Wilkie, and the anonymous JPP\&M reviewers for thoughtful comments on prior iterations of this essay. The author acknowledges the support of the Marley Foundation. Readers may contact the author for an unabridged iteration of this essay. involvement in Vietnam. I conclude with some discussion of broader implications.

If the premise is accepted that the current definition is too microscopic, it must also be concluded that it is not sufficiently macroscopic. What exactly does it mean to orient toward (macro)marketing? At the request of Greg Gundlach, Lauren Block, and Bill Wilkie, I spent a substantial amount of time trying to answer that question, as I prepared to write a chapter on macromarketing for their new book Explorations of Marketing in Society (2007). It soon became apparent that the long history of markets and marketing has been a largely macromarketing narrative; only recently has marketing become more micro and perhaps even atomistic (see, e.g., Wilkie and Moore 1999, 2003, 2006). ${ }^{2}$ This observation leads to other questions: For example, why does (macro)marketing include the prefix "macro"? Why does the current definition shared by the AMA not include "micro"? Given marketing's roots and its long history, shouldn't macromarketing be viewed simply as marketing; at the very least, shouldn't any definition of marketing more clearly delineate a macro agenda? In light of possible answers to these questions, and with consideration for the systemically complex and global challenges, a plausible and useful definition of marketing might read as follows:

Marketing is a form of constructive engagement-a societal function and a systemic set of processes for creating, communicating, and delivering value to customers and for managing customer and societal relationships in ways that benefit local and global stakeholders of these processes.

Next, I detail my rationale for this alternative definition, or some similarly expansive definition.

2Many scholars have struggled and still struggle to define macromarketing. In the previously cited chapter, I shared several popular definitions (e.g., Bartels and Jenkins 1977; Dixon 1979; Fisk 1981; Hunt 1981; Meade and Nason 1991; Shawver and Nickels 1979) and perspectives on historical development of the field and its formative conceptualizations (e.g. Alderson 1957; Bartels 1965; Breyer 1934; Fisk 1967; Grether and Holloway 1967; Holloway and Hancock 1964; Jones and Moniesen 1990; Schumpeter 1934; Shaw 1916; Sheth and Gardner 1982; Slater 1968; Vaile, Grether, and Cox 1952; Wilkie and Moore 1999, 2003). I also included some interpretations and literature beyond marketing (e.g., Danziger and Gillingham 2005; McMillan 2002; Polo 1958; Thucydides 1972 [circa 431 424 BC]). 


\section{(Macro)marketing}

As I suggested, the ideas of the (macro)marketing discipline, if not necessarily the name, have existed for millennia. Indeed, prior conceptualizations of marketing essentially seem to be what many scholars would now largely view as macromarketing. At this juncture, it might be helpful to address briefly the alleged micro and macro dichotomy. I do not believe that a dichotomy actually exists-precisely because all micromarketing activities occur within and thus derive meaning from some larger marketing system (see, e.g., Hunt 1981; Layton 2007; Lusch 2006)-though the extent of broadly meaningful impact from any particular marketing activity could be reasonably debated. Therefore, I have deliberately chosen to use the word "marketing" rather than "macromarketing" in the title of this essay and to reinforce some shortcomings of the current definition; note that I occasionally use the parenthetical attachment "(macro)" before "marketing."

So, although macromarketing is a relatively recent academic discipline and remains a somewhat nebulous construct, the essence of markets and marketing and their impact on societal welfare are old as humanity. Indeed, our species perhaps should be described as Homo marketus (Shultz 2005). ${ }^{3}$ We are the marketing animal. From the moment our ancestors crawled from the primal ooze and learned that cooperation and division of labor would abet survival, markets and marketing soon must have become integral to the processes of societal development. Entire societies and civilizations were organized accordingly. From the Fertile Crescent to Madison Avenue, we have been marketing, for better and worse. This long history is not adequately represented in the current definition, indicating that the definition may remain too focused on "micromarketing," despite the inclusion of "and society at large" at its end.

\section{(Macro)marketing in a World of Dilemmas}

Readers will recall that (macro)marketing fundamentally is concerned with the context of market(ing) problems and with solutions in relation to the welfare of the stakeholders of a marketing system or systems over time; moreover, the system in which marketers function is increasingly global, thus rendering everyone a stakeholder. ${ }^{4}$ The suggestion of a temporal dimension of this articulation draws attention to social traps: Marketers and consumers often engage in selfish activities that provide short-term benefits, sometimes with long-term harmful consequences to others and, tragically, even to themselves (e.g., Fisk 1981; Hardin 1968; Nason 2006; Shultz and Holbrook 1999). Thus, at least two (macro)marketing objectives are (1) to examine trade-offs required to overcome the sirens' song of immediate gratification and (2) to optimize outcomes for the largest number

3I thought I had cleverly coined this term and also the less elegant, Homo marketicus, but a quick Google search revealed several references to "him" (us), including entries in French, Polish, and Russian.

${ }^{4}$ The purpose of this essay is not to recount the origin, evolution, foci, and various definitions of the academic field of macromarketing; readers interested in those topics are directed to the review and discussion in Shultz (2007). of stakeholders in a marketing system not only now but also for future generations.

Distillation of the broad and varied literature reveals (macro)marketing as an amalgam of markets, marketing practices, and marketing systems; aggregations in the forms of units, consumers, firms, governments or other organizations, societies, regions, countries, and global alliances; social traps and commons dilemmas; and, now, subspecializations that address competition and markets, development, ethics or distributive justice, global policy, the environment, history, quality of life, and relevant ideas from myriad other disciplines. On reflection, the term "macro" may understate the orientation; perhaps "übermarketing" is more fitting. Nevertheless, comprehensive, eclectic, and inclusive conceptualizations, methods, practices, and definitions are useful in the complex world of dilemmas in which Homo marketus now dominates.

Consider a brief list of public policy topics relevant to marketing: globalization; environmentalism; energy; trafficking of weapons, people, drugs, and nuclear materials; cartels and malevolent alliances; religious and cultural intolerance; intellectual property rights; economic transition and/or development; public health crises (e.g., poverty, malnutrition, contaminated water, homelessness, malaria, and pandemics, such as HIV/AIDS, avian flu, cholera, and ebola); genetic engineering; societal angst and anomie; historical lessons (both learned and not learned); poor/despotic governance; and war. These topics are replete with dilemmas. Macromarketers understand that many of these topics interact with other forces; they are parts of broader systems and systemic failures. They require difficult choices. One choice is a decision to engage them-and factors that predict them-in scholarship and practice, with all the richness that is (macro)marketing.

In a finite global biosphere shaped by political and economic interests, all people are affected by one or more of the aforementioned problems. Governments, managers, and citizen consumers wittingly or unwittingly face dilemmas and regularly make choices that compound or help ameliorate them (see also Hunt and Vitell 2006). The current definition of marketing does not readily draw attention to them; ironically, however, failure to engage them without the eclectic toolkit of (macro)marketing may lead to disastrous results for Homo marketus. The following text offers a macromarketing synthesis as a possible framework to reorient marketing activities toward broader societal outcomes to the benefit of multiple global stakeholders of markets, marketing, and policies that affect and are affected by them.

\section{A Macromarketing Synthesis}

The synthesis requires envisioning marketing beyond the current definition-that is, construing marketing as constructive engagement. Here, I borrow from the literature in law and diplomacy (e.g., Forcese 2002) and social psychology (e.g., International Center for Cooperation and Conflict Resolution 2006). The theory and subsequent policy of constructive engagement argue for prosocial interactions among individuals, groups, firms, communities, and/or countries that are enmeshed in polarized and frequently intractable or destructive conflicts. Parties to the conflict can clash over any number of issues, though I submit that 
conflicts typically arise over resources and their management-that is, who controls them, how and where they are marketed and consumed, and the extent to which some superordinate authority justifies the chosen methods for marketing, consumption, and control. By definition, constructive engagement rules out ostracism and destructive engagement. Conversely, negotiation, cooperation, and exchange are important components to its process. Forcese (2002, p. 3) suggests that policy decisions and marketing activities must be "responsible" if they are to be truly constructive and that there are costs attached to parties who violate the generally agreed-on tenets intended to make engagement constructive. The quest for responsibility can be viewed as an effort to meld material interest and moral principle with a broader objective to abet the largest number of stakeholders in the process of engagement. Furthermore, constructive engagement is a step toward eliminating or at least reducing the allocation of mind-numbingly large sums of money for war expenditures and the concomitant opportunity costs to prosocial endeavors (e.g., Bilmes and Stiglitz 2006; Documents Center 2006).

Constructive engagement parallels sentiments espoused by macromarketers. For example, Alderson (1957), Layton and Grossbart (2006), and Shultz and colleagues (2005) contend that trade, commerce, and mutual prosperity facilitate peace and broader societal welfare. Arndt (1981) offers a political economy framework for examining marketing systems, with a concentration on societal institutions and the balancing of politics, hierarchies and markets, and their stakeholders. Building on Arndt's (1981) work, Taylor and Omura (1994) suggest that the efficacy of engagement should be assessed using several criteria, including behavioral interdiction, historical perspectives, apoliticalness, nonuniversality, and internal and external forces.

The preceding body of work from several disciplines provides an impetus for a possible synthesis of ideas and practices. Figure 1 illustrates a plausible macromarketing synthesis for constructive engagement in a global marketing system. It is not intended to be exhaustive, given the extraordinary complexities of history, culture, politics, people, and the innumerable filters through which we view them, nor is it intended to serve as a linear protocol for decision making. Rather, it is presented here simply to demonstrate the relevance of macromarketing and its academic subspecializations to seemingly intractable dilemmas relevant to the survival or possible demise of Homo marketus. I use the dilemma of war versus constructive engagement to illustrate a possible application of a macromarketing synthesis. War is an extreme example; it is inherently destructive and has global high-stakes repercussions for marketers and citizen consumers. Note also that many other societal problems I listed degrade humanity and exacerbate tensions and thus foment hostilities that can spiral into war, causing still more destruction and suffering.

\section{Political Considerations}

In general, the model in Figure 1 flows from top to bottom. The United States and Vietnam are provided as examples for "External Stakeholders" and "Country," respectively. Although they are used to make key points, the framework is applicable to relationships between other countries or among factions and organizations within countries. Afghanistan, Sudan, India, Pakistan, the Koreas, the Caucasus, Sri Lanka, and other actual or potential flashpoints also capture attention. I considered focusing only on the Iraq war and its stakeholders throughout the Middle East and beyond, especially in light of current events and the prior reference to marketing's possible emergence in the Fertile Crescent (artifacts of which are found in present-day Iraq), but unlike the Iraq war at this time, the Vietnam War provides tangible lessons about macromarketing's role in recovery, peace, and prosperity.

For most readers, interpretation will begin from the perspective of external stakeholders and their options for engagement with the foreign country. Vietnamese readers would likely begin their interpretation more toward the center of the model. Isolation, ignorance, antipathy, myopia, historical clashes, extant conflict, and other factors could give pause to countries about ways to engage each other. This certainly was the case in U.S.-Vietnam relations for more than half a century (e.g., Fitzgerald 1972; Karnow 1997; Shultz et al. 2006). Among many external stakeholders are the U.S. government, companies, nongovernmental organizations, and U.S. citizens, as well as countries that border Vietnam. Indeed, the ripple effect of U.S. involvement in Vietnam was/is felt globally.

The Vietnam War, or the American War, as Vietnamese call it, was a systemically complex historical event. Nuanced analysis reveals that it was several conflicts. In some ways, it was the continuation of numerous invasions, wars, and occupations over the span of 2000 years, which have profoundly affected the Vietnamese psyche and their perceptions of outsiders. In many respects, it was a continuation of the French-Vietnamese war, essentially a struggle for independence from colonial occupation (including resource and market exploitation) that officially ended in 1954 and that resulted in a north-south partition of the country. It was a kind of postcolonial war, with manifestations of civil war (north versus south, communist versus capitalist, ethnic minorities versus dominant Kinh) and religious war (Roman Catholics versus Cao Dai versus Hoa Hao versus Buddhists versus atheists versus others). Geopolitically, it was a client war in which two superpowers, the United States and the Soviet Union, used this country and other countries to influence ideology and alliances. Similar to all wars, the Vietnam War clearly and greatly affected markets and marketing; assortment, allocation, and availability of resources; and quality of life. The Vietnam War also ended the lives of 2 million Vietnamese and more than 58,000 Americans.

Motives for engagement principally included economic gain (e.g., access to physical goods, human resources, and markets) and/or societal welfare, and official policy was driven by interests in outcomes that affected both, though perhaps in unbalanced or dysfunctional proportions. Tuchman (1984) writes eloquently of the dysfunctional path, or the "march of folly," often chosen by policy makers, from Troy to Vietnam, in which leaders made poor decisions that result in inevitably poor outcomes..$^{5}$ Conversely, a macro-

5Tuchman, a historian, shares ideas remarkably parallel to those espoused by macromarketers, discussing commons dilemmas and social traps. 


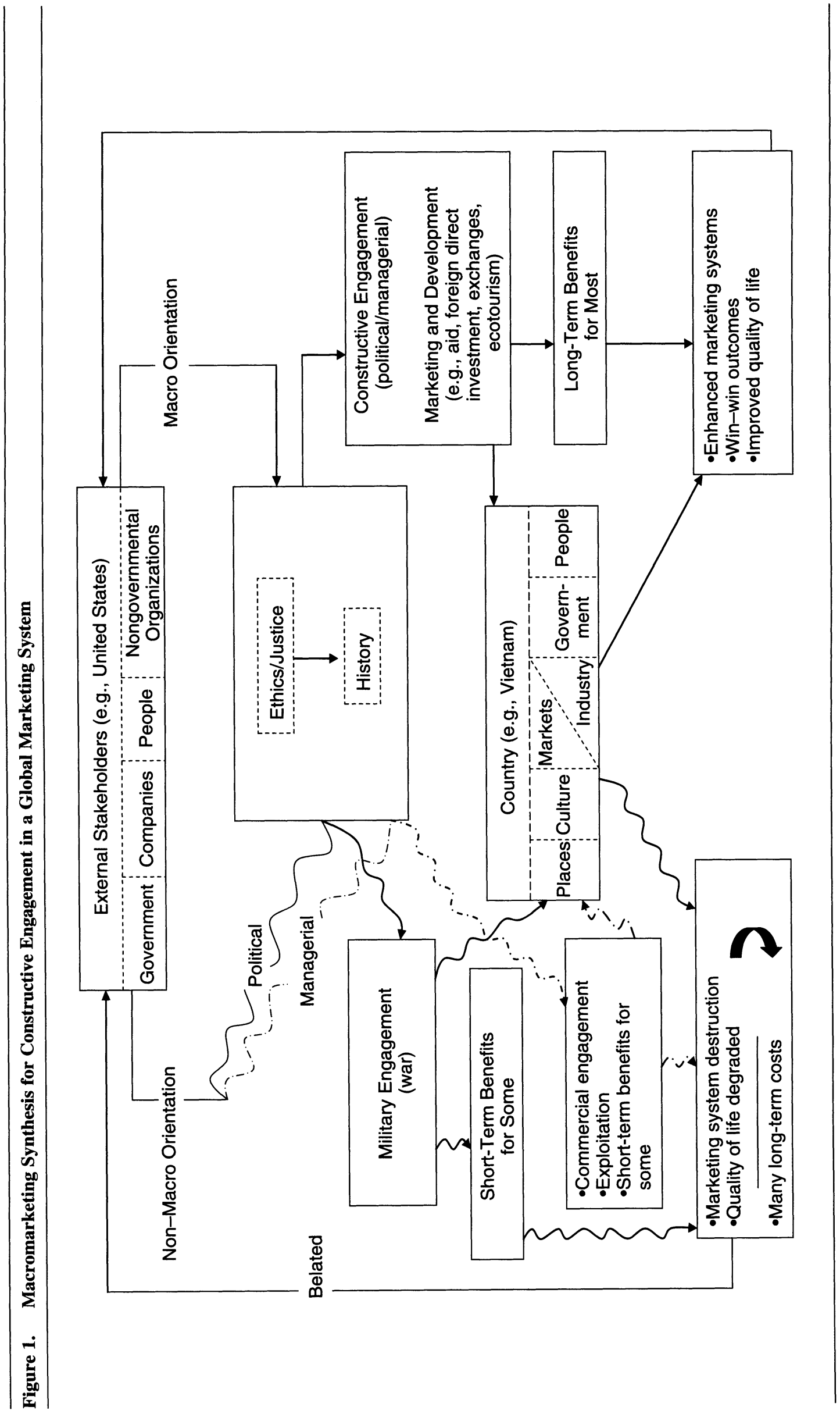


marketing orientation toward constructive engagement would begin with a concern for ethical decision making and distributive justice; it also would attend to historical narratives (Jones and Shaw 2006; Taylor and Omura 1994), including cultural sensitivities. ${ }^{6}$ Laczniak and Murphy (2006) share an ethical position that hints at broad spatial and temporal considerations for the stakeholders of the system, with important implications for the conduct of marketers; they also suggest that their position may not be favored by many marketers, an issue to which I return subsequently.

In Figure 1, the crooked line labeled "Political" indicates that U.S. policy makers (circa 1945-1995) essentially opted for a nonmacromarketing orientation and either circumvented these issues or did not understand them, resulting in the Vietnam War and subsequent devastation to much of the Vietnamese marketing system (as well as adjacent marketing systems in Cambodia and Laos). ${ }^{7}$ The war also came at considerable cost to American society and continues to affect the collective American psyche, U.S. foreign policy, and marketing activities.

The subsequent withdrawal of the United States from Vietnam and greater Indochina in 1975, coupled with the ascent to power of the Vietnamese Communist Party, led to a series of devastating Marxist-Leninist policies and precipitated Vietnam's wars with Cambodia and China. By 1979 , in the wake of decades of war, ineffectual central economic planning, and a U.S.-led trade embargo, Vietnam had become one of the ten poorest countries in the world (e.g., Karnow 1997; Shultz, Pecotich, and Le 1994). The country was a failed (non)marketing system, unable to meet subsistence needs for a vast number of the citizenry.

The collapse of the Soviet Union, Vietnam's largest benefactor, and the geopolitical shift toward market economies forced Vietnam's transition-namely, the creation of a rudimentary marketing system intended to enhance the welfare of the people, a central tenet of macromarketing. Without overstatement, (macro)marketing subsequently saved Vietnam. The simple but elegant Doi Moi policy, enacted by Vietnamese leaders in 1986, enabled farmers to set prices and to retain a portion of their profits. In the span of three years, Vietnam was transformed from a net importer of rice, on the brink of famine, to the world's third largest rice exporter (e.g., Shultz 1997). This success set the foundation for a sectorwide marketing renaissance. Exponential increases in trade and export development soon followed, which in turn expedited a trade agreement with

\footnotetext{
${ }^{6}$ Vietnam has a rich, complex history. Having spent much of the past 15 years studying Vietnam's history, culture, and evolving policy and marketing system, I am struck by the tragic level of ignorance, indifference, and/or hubris evinced by powers that have interacted with Vietnam over millennia. United States policies revealed little apparent understanding of or interest in recent history and extant agreements or in a complex history and sophisticated culture that can be traced back at least to the seventhcentury BC (e.g., Taylor 1983) and, by some archeological accounts, a contiguous and distinct Vietnamese history that can be traced back 4000 years or longer (e.g., Hoang and Bui 1979).

${ }^{7}$ My example of U.S. involvement in Vietnam or elsewhere should not be construed as anti-American or anti-West. China has also advanced 19 military ventures into Vietnam over two millennia. Vietnam has its own history of military, political, and cultural expansion from the Red River to the Mekong, resulting in devastation to Cham civilization and expropriation of Khmer territories.
}

the United States and a new era of constructive engagement between the two countries. The impact on quality of life for the majority of Vietnamese has been dramatic (e.g., Shultz, Nguyen, and Westbrook 2006; World Bank 2006), and some observers have speculated that Vietnam will meet Millennium Project goals for poverty reduction years ahead of schedule (Foreign Affairs 2005; United Nations 2004). ${ }^{8}$

Insights from the macromarketing orientation favor such constructive engagement, which is manifested in marketing and development. Possible examples include various forms of aid; foreign direct investment; mutually beneficial political, cultural, economic, technological, academic, and professional exchanges; and ecotourism. All potentially produce long-term benefits by bolstering the indigenous marketing systems and by connecting the elements of "country" to global marketing systems. Win-win outcomes for external and internal stakeholders are expected to follow, as measured by improvements in quality of life.

Critics might contend that most, if not all, wars occur because constructive engagement fails; despots or despotic systems emerge, forcing military options with the objective of restoring minimally acceptable marketing systems, at least as determined by external stakeholders. I submit that despots and despotic systems do not emerge in a vacuum; they are created by failures that can be traced to disregard for ethical decision making, to a lack of concern for distributive justice, and/or to historical ignorance. Critics might also argue that constructive engagement, however well intentioned, can produce suboptimal outcomes that must be corrected. This criticism is fair-thus, the inclusion of a feedback loop from quality-of-life measures back to the external and internal stakeholders, to determine whether the various forms of engagement are indeed constructive and to encourage the best possible outcomes for the largest number of people, preferably in ways commensurate with the values of external stakeholders (e.g., Osgood 1962). Note that a similar, "belated" feedback loop is provided for the nonmacromarketing orientation. Short of Armageddon, war eventually necessitates reconsideration of policy, which will result in still more war, isolation, or some form of constructive engagement.

\section{Managerial Considerations}

The public has good reasons to encourage macromarketing, but managerial considerations also support a macromarketing orientation (Zif 1980). Here, I diverge from my friend and colleague, Bob Nason (2006), and converge in some respects with another friend and colleague, Shelby Hunt (1981; see also Hunt and Vitell 2006), as well as with the marketers who articulated the current definition of marketing. Macro must meld with micro (i.e., managerial marketing) if only for the purpose of understanding that micro

${ }^{8}$ To expand on Footnote 5, an important caveat is the strong motive for war among some stakeholders in, for example, the global militaryindustrial complex and rank opportunists of all walks and sizes that gain from armed conflict, which can and often does foment circumvention of key elements of a macromarketing synthesis. This phenomenon revisits the insidiousness and perniciousness of the march of folly and social traps discussed by Shultz and Holbrook (1999); in the current illustration, it is evinced by profiteering at the long-term cost to sustainable peace, prosperity, and quality of life. 
decisions have huge impacts on macro interests. The artifacts of Homo marketus, the marketing firms (e.g., oil companies, consumer-goods companies), arguably have the greatest impact on the global ecosystem in which we all have stakes. Whether this reality is good can be debated, but to ignore it is to eliminate an important and possibly fruitful conduit for meaningful research that can improve marketing systems and ultimately enhance quality of life. Moreover, including micro or managerial orientations creates opportunities to persuade managers to view their vested interests in desirable macro outcomes. Such inclusion positions the marketing firm as a potential vanguard of constructive engagement and may also provide a possible antidote to the "little-impact" syndrome that Nason (2006) mentions.

Indeed, the growing marketing and business paradigm sweeping the globe would seem to demand the inclusion of marketers and managers in macromarketing discourse. In other words, managerial perspectives must be addressed if engagement is to be constructive. All stakeholders must have a greater appreciation for the amalgamation of consumer interests, government interests, corporate profit motives, and global concerns about sustainability. Conflicting stakeholder interests should be factored into negotiated agreements; otherwise, more powerful stakeholders (typically, micromarketers) will have little incentive to engage constructively, reducing the probability for win-win outcomes for the largest number of stakeholders engaged (Nill and Shultz 1997).

Firms with this tack in developing/transitioning/recovering markets incidentally are more likely to have sustainable commercial success. A clear understanding and respect for the broad marketing system-its history and cultural ubiquities, regulatory environment, administrative practices, ethical decision making, and tangible concern for the welfare of the people in that system-often are predictors for financial success.

Several companies have experienced problems in Vietnam because their managers did not understand several factors in that system. In my chapter for Gundlach, Block and Wilkie's (2007) book, for example, I discuss in some detail the problems that Nike encountered during the 1990s. Among those problems were labor difficulties and antagonisms with the Vietnamese government, which became a public relations nightmare that degraded Nike's global brand image. These problems are represented in the "Commercial" crooked dashed lines in Figure 1.

Similar to many companies confronted with bad press, Nike initially stonewalled its critics (e.g., Greenhouse 1997). Eventually, however, Nike management interpreted its misfortune as an opportunity to make corrections. Interviews with Nike employees, participants in Nike's Vietnamese value chain, and Vietnamese government officials all indicate that Nike has indeed corrected policies and practices to the benefit of many stakeholders. Nike and its partners now are among the largest employers in Vietnam; they have among the most favorable working conditions and pay among the highest factory wages. Nike has refurbished local infrastructure and has commenced recycling and environmental preservation programs; it is involved in the welfare of its employees through education advance- ment, employee assistance, and other human-resources development programs. Some of these efforts have produced positive, unexpected consequences. Thanks to the microloan program, women have started new enterprises, which create still more jobs and lift still more people out of poverty; it has also been discovered that income-generating spouses are subject to less domestic violence (e.g., Ardrey, Pecotich, and Shultz 2006). Incentive structures and skills transfer are making Nike employees more valuable in the labor market, which creates options and drives up these employees' wages. All these outcomes are occurring in work environments that many observers believe can be a benevolent model for the country and perhaps the developing world (e.g., Fair Labor Association 2006). ${ }^{9}$

Despite a tangible shift toward a macromarketing orientation, another possible dilemma for some readers may be whether the relatively superior working conditions and wages of Nike's factories in Vietnam, which fall below generally accepted standards in the United States and Europe, should remove Nike from criticism. In a country such as Vietnam, which adds 1.5 million workers to its labor force every year and with a historically dominant government sector incapable of providing enough jobs, the Vietnamese people overwhelmingly favor the likes of Nike and support the larger policy of constructive engagement. The world community also is better off because it becomes enriched by greater understanding of and experience with Vietnamese culture and products.

In summary, a new synthesis in the form of a macromarketing orientation toward constructive engagement can render adversarial relationships more cooperative, beneficial, and sustainable. Furthermore, it can be reasonably concluded that the Untied States, through foreign direct investment and other forms of constructive engagement, has won more hearts and minds in Vietnam and throughout Indochina in the past decade than did many other U.S. endeavors that operated in Vietnam during the late 1960s and early 1970s. To date, net effects of constructive engagement with Vietnam include poverty reduction, less authoritarian governance, and greater political transparency; corporate success and Vietnam's inclusion in the World Trade Organization; global customer satisfaction; and measurable improvements in quality of life for most Vietnamese (e.g., Central Intelligence Agency 2006; Shultz, Nguyen, and Westbrook 2006; United Nations 2002). A new era of peaceful, mutually beneficial U.S.-Vietnam relations now enables Americans and Vietnamese to seek new opportunities for cooperation to the betterment of both countries and the global community; these include active cooperation to effect solutions for global challenges, such as HIV/AIDS, infant blindness, drug and sex trafficking, energy shortages, urban decay, waste handling, avian flu, Mekong exploitation, fishery and

\footnotetext{
9This discussion is based on my interviews from 2001 to 2007 with several strata of Nike management in Vietnam and the United States, as well as with Nike factory workers and their families, participants in the microloan program, various Vietnamese government authorities at national and local levels, and representatives from the Vietnam Women's Worker Union. This example and some text in the "Meaningful Marketing in the Future" section borrow from and expand on my chapter in Gundlach, Block, and Wilkie's (2007) book.
} 
forest management, technology transfer, and security (e.g., Cao 2006; Hai 2006; Nguyen 2005). Compared with the state of relations between the Untied States and Vietnam only two decades ago, we seem to be on the cusp of a golden era for mutual cooperation and prosperity.

\section{Meaningful Marketing in the Future}

As the discussion about the definition, or the essence, of marketing continues, the world is confronted with dilemmas of supreme relevance to marketers and their stakeholders. However, as the current definition suggests, few scholars and practitioners in "mainstream" marketing seem to be engaging these "big issues."

Regardless of one's position on Vietnam or any number of current flashpoints and dilemmas, solutions require constructive engagement, perhaps as illustrated in the macromarketing synthesis. At both political and managerial levels in Vietnam and potentially elsewhere, the process necessitates greater understanding of historical and cultural forces, coupled with far-reaching systemic analysis. Solutions ultimately require a willingness to invoke polices and practices that will result in some short-term costs but also better longterm benefits for stakeholders in a particular marketing system/society, as well as the larger global community.

Scholars outside marketing increasingly embrace this perspective (e.g., Sen 2006; cf. Newman, Barabasi and Watts 2006; for one marketer's perspective on complexity, see Holbrook 2003). Equally important, corporate leaders, politicians, and pundits also embrace it. For example, Friedman (2005a, b, c; 2006) now extols "The Geo-Green Alternative," positing that the most intractable challenges-the Middle East saga, war, global warming, the rise of China, energy shortages and alternative sources, environmentally friendly technology and product development, job creation, terrorism, political repression, religious intolerance, human rights, failed states, rogue states, nuclear proliferation, fuel prices, and taxes-all are interconnected. These are tangible foci for meaningful marketing research and practice, perhaps most efficaciously examined through a new synthesis. They necessitate a sound integrative policy implemented as constructive engagement to ensure the best long-term wellbeing for countries, societies, markets, and individual consumers. In a word, they demand macromarketing.

The markets of the ancient world (e.g., the Athenian agora) were largely intended to be a benevolent place, integral to society well beyond exchange, buyer-seller relationships, or organizational outcomes (Camp 1986; see also Mittelstaedt, Kilbourne, and Mittelstaedt 2006). 10 Given that the world is now the agora, it is incumbent on marketers and policy makers to drive constructive engagement as a new marketing synthesis and to make the global agora/market a benevolent place.

Marketing still has so much to offer the world. Without a definition that encourages macromarketing orientation through constructive engagement, however, the world will remain an unjust, dangerous, and endangered place. It perhaps would be unduly optimistic, even for the editor of the

10 Often considered to be among the most warring Greek city-states, Sparta had no such venue (Camp 2006).
Journal of Macromarketing, to believe that any single research project or publication could solve or mitigate the complex challenges confronting Homo marketus. However, a research career dedicated to the interaction of marketing and society could have a positive impact. A macromarketing movement within the academy-including a definition of marketing that more readily captures macromarketing certainly could reach critical mass to orchestrate research, managerial practice, and policy in ways that invoke constructive engagement, enhance the quality of our lives, and ensure our survival.

\section{References}

Alderson, Wroe (1957), Marketing Behavior and Executive Action. Homewood, IL: Richard D. Irwin.

Ardrey, W., A. Pecotich, and C. Shultz (2006), "Entrepreneurial Women as Catalysts for Socioeconomic Development in Transitioning Cambodia, Laos, and Vietnam," Consumption, Markets and Culture, 9 (4), 277-300.

Arndt, Johan (1981), "The Political Economy of Marketing Systems: Reviving the Institutional Approach," Journal of Macromarketing, 1 (2), 36-47.

Bartels, Robert (1965), "Development of Marketing Thought: A Brief History," in Science in Marketing, George Schwartz, ed. New York: John Wiley \& Sons, 47-69.

and Roger L. Jenkins (1977), "Macromarketing," Journal of Marketing, 41 (October), 17-20.

Bilmes, Linda and Joseph Stiglitz (2006), "The Economic Costs of the Iraq War: An Appraisal Three Years After the Beginning of the Conflict," National Bureau of Economic Research Working Paper 12054, Cambridge, MA.

Breyer, Ralph (1934), The Marketing Institution. New York: McGraw-Hill.

Camp, John (1986), Athenian Agora: Excavations in the Heart of Classical Athens. New York: Thames and Hudson.

(2006), personal interview with author, Athenian Agora, (July 18).

Cao, Duc Phat (2006), Minister of Agriculture and Rural Development for the Socialist Republic of Vietnam, outcomes from personal meeting with author regarding future U.S.-Vietnam collaboration, Hanoi (July 25).

Central Intelligence Agency (2006), World Factbook: Vietnam: Economy, (accessed November 20, 2006), [available at http://www.worldfactbook.org].

Danziger, Danny and John Gillingham (2005), 1215: The Year of the Magna Carta. New York: Touchstone.

Dixon, Donald (1979), "The Origins of Macromarketing Thought" in Macromarketing: New Steps on the Learning Curve, George Fisk and Robert Nason, eds. Boulder: University of Colorado, Business Research Division.

Documents Center (2006), "Statistical Summary America's Major Wars," data to June 13, 2001, provided by University of Michigan Library, (accessed November 20, 2006), [available at http://www.lib.umich.edu/govdocs/stmil.html], and Louisiana State University, (accessed November 20, 2006), [available at http://www.cwc.lsu.edu/cwc/other/stats/warcost.htm].

Fair Labor Association (2006), 2006 Annual Public Report, (accessed November 21, 2006), [available at http://www.fair labor.org/]. 
Fisk, George (1967), Marketing Systems: An Introductory Analysis. New York: Harper and Row.

(1981), "An Invitation to Participate in Affairs of the Journal of Macromarketing," Journal of Macromarketing, 1 (1), 3 .

Fitzgerald, Frances (1972), Fire in the Lake: The Vietnamese and Americans in Vietnam. New York: Vintage Books.

Forcese, Craig (2002), "Globalizing Decency: Responsible Engagement in an Era of Economic Decency," Yale Human Rights Law Journal, 5, 1-55.

Foreign Affairs (2005), "Vietnam Goes Global," sponsored section, 84 (September-October), 76-77.

Friedman, Thomas (2005a), "The Geo-Green Alternative," The New York Times, (January 30), Section 4, 17.

(2005b), "Geo-Greening by Example," The New York Times, (March 27), Section 4, 11.

(2005c), "No Mullah Left Behind," The New York Times, (February 13), Section 4, 15.

(2006), "The Green Leap Forward," The New York Times, (November 17), Section A, 31.

Greenhouse, Steven (1997), "Nike Shoe Plant in Vietnam Is Called Unsafe for Workers," The New York Times, (November 8), (accessed December 3, 2004), [available at http://www. mindfully.org/WTO/Nike-Vietnam-Unsafe.htm].

Grether, E.T. and Robert Holloway (1967), "Impact of Government upon the Marketing System," Journal of Marketing, 31 (April), 1-5.

Gundlach, G., L. Block, and W. Wilkie, eds. (2007), Explorations of Marketing in Society. Mason, OH: Thomson Learning.

Hai, Bui Manh (2006), Vice Minister of Science and Technology for the Socialist Republic of Vietnam, outcomes from personal meeting with author regarding future U.S.-Vietnam collaboration, Hanoi (July 24).

Hardin, Garrett (1968), "The Tragedy of the Commons," Science, $162,1243-48$

Hoang, Xuan Chinh and Van Tien Bui (1979), "Van Hoa Dong Son Va Cac Trung Tam Van Hoa Trong Thoi Dai Kim Thi o Viet Nam," Khac Co Hac, 31 (August), 40-48.

Holbrook, M. (2003), "Adventures in Complexity: An Essay on Dynamic Open Complex Adaptive Systems, Butterfly Effects, Self-Organizing Order, Coevolution, the Ecological Perspective, Fitness Landscapes, Market Spaces, Emergent Beauty at the Edge of Chaos, and All That Jazz," in Academy of Marketing Science Review, Vol. 6, (accessed November 16, 2006), [available at http://www.amsreview.org/articles/holbrook062003.pdf].

Holloway, Robert J. and Robert S. Hancock (1964), The Environment of Marketing Behavior. New York: John Wiley \& Sons.

Hunt, Shelby (1981), "Macromarketing as a Multidimensional Concept," Journal of Macromarketing, 1 (1), 7-8.

and Scott Vitell (1986), "A General Theory of Marketing Ethics," Journal of Macromarketing, 6 (1), 5-16.

and - (2006), "The General Theory of Marketing Ethics: A Revision and Three Questions," Journal of Macromarketing, 26 (2), 143-53.

International Center for Cooperation and Conflict Resolution, Teachers College, Columbia University (2006), "Project on Meta-Framing in Complex Conflicts," (accessed May 31, 2006), [available at http://www.tc.columbia.edu/icccr/ researchCurrent3.html].
Jones, D.G.B. and David D. Monieson (1990), "Early Development of the Philosophy of Marketing Thought," Journal of Marketing, 54 (January), 102-113.

and Eric Shaw (2006), "Historical Research in the Journal of Macromarketing, 1981-2005," Journal of Macromarketing, 26 (2), 178-92.

Karnow, Stanley (1997), Vietnam: A History. New York: Penguin.

Laczniak, Eugene and Patrick Murphy (2006), "A Normative Approach for Evaluating and Improving the Ethics of Marketing Practice in Society," Journal of Macromarketing, 26 (2), 154-77.

Layton, Roger A. (2007), "Marketing Systems: A Core Macromarketing Concept," Journal of Macromarketing, 27 (3), $227-42$.

- and Sanford Grossbart (2006), "Macromarketing: Past, Present, and Possible Future," Journal of Macromarketing, 26 (2), 193-213.

Lusch, R. (2006), "The Small and Long View," Journal of Macromarketing, 26 (2), 240-44.

McMillan, John (2002), Reinventing the Bazaar: The Natural History of Markets. New York: Norton.

Meade, William and Robert Nason (1991), "Toward a Unified Theory of Macromarketing: A Systems Theoretic Approach," Journal of Macromarketing, 11 (1), 72-82.

Mittelstaedt, John, William E. Kilbourne, and Robert A. Mittelstaedt (2006), "Macromarketing as Agorology: Macromarketing Theory and the Study of the Agora," Journal of Macromarketing, 26 (2), 131-42.

Nason, Robert (2006), “The Macromarketing Mosaic," Journal of Macromarketing, 26 (2), 219-23.

Newman, Mark, Albert-Laszlo Barabasi, and Duncan Watts (2006), The Structure and Dynamics of Networks. Princeton, NJ: Princeton University Press.

Nguyen, Tam Chien (2005), Ambassador of Socialist Republic of Vietnam to the United States, outcomes from personal meeting with author regarding future U.S.-Vietnam collaboration, Tempe, AZ, (October 4).

Nill, A. and C. Shultz (1997), "Cross Cultural Marketing Ethics and the Emergence of Dialogic Idealism as a Decision Making Model," Journal of Macromarketing, 17 (Fall), 4-19.

Osgood, Charles (1962), An Alternative to War or Surrender. Urbana: University of Illinois Press.

Polo, Marco (1958), The Travels, Ronald Latham, trans. New York: Penguin.

Schumpeter, Joseph (1934), The Theory of Economic Development; an Inquiry into Profits, Capital, Credit, Interest, and the Business Cycle. Cambridge, MA: Harvard University Press.

Sen, Amartya (2006), Identity and Violence: The Illusion of Destiny. New York: W.W. Norton.

Shaw, Arch Wilkinson (1916), An Approach to Business Problems. Cambridge, MA: Harvard University Press.

Shawver, Donald and William Nickels (1979), "A Rationalization for Macromarketing Concepts and Measures," in Macromarketing: New Steps on the Learning Curve, George Fisk and Robert Nason, eds. Boulder: University of Colorado Business Research Division.

Sheth, Jadgish and David Gardner (1982), "History of Marketing Thought: An Update," in Marketing Theory: Philosophy of Science Perspectives, Ronald Bush and Shelby Hunt, eds. Chicago: American Marketing Association, 52-58. 
Shultz, C.J. (1997), "Improving Life Quality for the Destitute: Contributions from Multiple-Method Fieldwork in WarRavaged Transition Economies," Journal of Macromarketing, 17 (1), 56-67.

(2005), "The Future of Marketing," panel presentation at the 30th Annual Macromarketing Conference, St. Petersburg, FL (May 30).

(2007), "Macromarketing," in Explorations of Marketing in Society, G. Gundlach, L. Block, and W. Wilkie, eds. Mason, $\mathrm{OH}$ : Thomson Learning, 766-84.

T. Burkink, B. Grbac, and N. Renko (2005), "When Policies and Marketing Systems Explode: An Assessment of Food Marketing in the War-Ravaged Balkans and Implications for Recovery, Sustainable Peace, and Prosperity," Journal of Public Policy \& Marketing, 24 (Spring), 24-37.

, D. Dapice, A. Pecotich, and H.D. Doan (2006), "Vietnam: Expanding Market Socialism and Implications for Marketing, Consumption and Socio-Economic Development," in Handbook of the Markets and Economies of East Asia, Southeast Asia, Australia and New Zealand, A. Pecotich and C. Shultz, eds. Armonk, NY: M.E. Sharpe.

and M. Holbrook (1999), "Marketing and the Tragedy of the Commons: A Synthesis, Commentary, and Analysis for Action," Journal of Public Policy \& Marketing, 18 (Fall), 218-22.

, Dinh Tho Nguyen, and D. Westbrook (2006), "Subjective Quality of Life and Market Activity in Vietnam: New Data and Extensions," in Proceedings of the 31st Macromarketing Conference: Macromarketing, the Future of Marketing? M. Layton, R. Layton, and B. Wooliscroft, eds. Dunedin, NZ: University of Otago, 93-94.

, A. Pecotich, and K. Le (1994), "Changes in Marketing Activity and Consumption in the Socialist Republic of Vietnam," Research in Consumer Behavior, 7, 225-57.
Slater, Charles C. (1968), "Marketing Processes in Developing Latin American Societies," Journal of Marketing, 32 (July), 50-55.

Taylor, C.R. and G.S. Omura (1994), "A Comparison of Alternative Paradigms for Describing Economic Development," Journal of Macromarketing, 12 (2), 6-20.

Taylor, K.W. (1983), The Birth of Vietnam. Berkeley: University of California Press.

Thucydides (1972), History of the Peloponnesian War, Rex Warner, trans. New York: Penguin.

Tuchman, B. (1984), The March of Folly: From Troy to Vietnam. New York: Random House.

United Nations (2002), Vietnam Household Living Standards Survey 2002. Hanoi: General Statistical Office/UNDP Hanoi.

(2004), Raw data from Vietnam Household Living Standards Survey, sponsored by UNDP Hanoi.

Vaile, R., E. Grether, and R. Cox (1952), Marketing in the American Economy. New York: Ronald Press.

Wilkie, William and Elizabeth Moore (1999), "Marketing's Contributions to Society," Journal of Marketing, 63 (Special Issue), 198-218.

and (2003), "Scholarly Research in Marketing. Exploring the '4 Eras' of Thought Development," Journal of Public Policy \& Marketing, 22 (Fall), 116-46.

_ and (2006), "Macromarketing as a Pillar of Marketing Thought," Journal of Macromarketing, 26 (2), 224-32.

The World Bank (2006), "Vietnam: Social Indicators," (accessed November 20, 2006), [available at http://web.worldbank.org/ WBSITE/EXTERNAL/COUNTRIES/EASTASIAPACIFIC EXT/VIETNAMEXTN/0,,contentMDK:20210474 menuPK:38 7591 pagePK:1497618 piPK:217854 theSitePK:387565,00. html].

Zif, J. (1980), "A Managerial Approach to Macromarketing," Journal of Marketing, 44 (Winter), 36-45. 


\title{
Implications of the Revised Definition of Marketing: From Exchange to Value Creation
}

\author{
Jagdish N. Sheth and Can Uslay
}

\begin{abstract}
The distinctive difference between the 1985 and the 2004 American Marketing Association definitions of marketing is the lack of exchange. In the new definition, a focus on creating and delivering value through customer relationships replaces the historical focus on the exchange paradigm. The authors welcome this change and discuss its implications, the limits of the exchange paradigm, the merits of value creation, and the future paradigm for marketing.
\end{abstract}

E xchange has arguably been the foundational construct in marketing for several decades (Alderson 1957; Bagozzi 1975; Houston and Gassenheimer 1987; Hunt 1976; Kotler and Levy 1969). The shift toward the exchange paradigm was crowned by the American Marketing Association (AMA) when the word "exchange" made it into the official definition of marketing in 1985 (the first revision since the adoption of the original definition in 1935) as a central theme: "Marketing is ... to create exchanges that satisfy individual and organizational goals." Since then, the prevalence of exchange in marketing has been unchallenged. "The act of exchange is the consummation and confirmation of the marketing process, and brings the marketing concept to life" (Anderson, Challagalla, and McFarland 1999, p. 9). "[T] here is a growing consensus that exchange forms the core phenomenon for the study of marketing" (Bagozzi 1975, p. 32). "Exchange is a central concept in marketing, and it may well serve as the foundation for that elusive 'general theory of marketing", (Bagozzi 1975, p. 39).

Given its gravity in marketing literature, and once advocated as the fundamental subject matter of marketing (Bagozzi 1975, 1979), the word "exchange" is curiously missing in the new definition of marketing. In the new definition, a focus on creating and delivering value through customer relationships permeates over creating satisfactory exchanges. Could exchange be justifiably eradicated from the official definition of marketing? Was this change inevitable for marketing reform? We argue that the replacement of exchange with value creation is the distinctive difference between the 1985 and the 2004 AMA definitions of marketing. ${ }^{1}$ We welcome this change and argue for the

1Another notable difference is a managerial viewpoint in neglect of the broad impact of marketing on society. This is not entirely new; there has been an unfortunate trend toward a narrowing managerial focus in previous iterations (e.g., Gundlach 2006; Wilkie 2006). In this article, we limit

Jagdish N. Sheth is Charles H. Kellstadt Professor of Marketing, Goizueta Business School, Emory University (e-mail: jag@jagsheth. com). Can Uslay is Assistant Professor of Marketing, Argyros School of Business and Economics, Chapman University (e-mail: uslay@ chapman.edu). positive implications of a shift away from the sacred cow of exchange. To make our point, we discuss the limits of the exchange paradigm, the merits of the value creation paradigm, and the future paradigm for marketing.

\section{The Exchange Paradigm}

Exchange, the act of giving or taking one thing in return for another, is not unique to marketing and, by unspoken acclamation, is a central concept in virtually all human sciences (Anderson, Challagalla, and McFarland 1999). Exchange research can be found in economics, sociology, psychology, anthropology, political science, semiotics, education, theology, philosophy, medicine, military science, management, law, communication, and fine and performing arts. In his seminal work, Bagozzi (1975) describes three types of exchange: restricted, generalized, and complex. Most marketing exchanges are generalized (at least three actors benefiting one another only indirectly) and complex (at least three actors with at least one direct exchange and a web of relationships) rather than simply restricted exchanges (i.e., two-party reciprocal) (Bagozzi 1975). Marketing exchanges are also mostly mixed with both utilitarian (economic) and intangible (symbolic) aspects. These exchanges can be both internal to the household/business organization and external (Lusch, Brown, and Brunswick 1992).

Marketing scholars have perceived exchange as the underlying key phenomenon for desired outcomes (Houston, Gassenheimer, and Maskulka 1992), with the premise that societies' problems are solved only when exchanges occur (Bagozzi 1979). The proponents of the exchange paradigm seem to agree that "[e]xchange is not an end in itself" (Houston and Gassenheimer 1987, p. 10) and that "end is need satisfaction" (Houston, Gassenheimer, and Maskulka 1992, p. 131). Thus, the general framework for examining exchange has been exchanges $\rightarrow$ need satisfaction.

We contend that this framework is limiting for the conceptualization of marketing. There are practical limits on the generic applicability of all exchange processes, including the conventional marketing process (Anderson, Challagalla, and McFarland 1999, p. 11). Perceiving all human

our attention to the lack of exchange and leave the inquiry of the narrowing focus to other scholars. 